\title{
Leprosy Folk-lore in Southern Nigeria
}

James A. K. BRown.

The fear of leprosy is not only general, but also very intense, - so much so that the native name of the disease (Opo) is seldom used, lest its repetition should cause the sickness to come upon the speaker. Descriptive words are preferred, "Oria-Ocha "-white sickness; " Nchiche "changing of the skin; "Iberiekpe "- the sickness following the inheritor of the property of a man dying of the disease. One has occasionally noticed a reticence, over the use of the English word, by interpreters, "the sickness" being the designation adopted. A teacher told me that once, when teaching hygiene, he showed a picture of a leper, and asked a boy to touch it, but he was too afraid.

The natives ascribe the disease to various causes, some of which apply to other ailments too. They may be grouped under (1) Supernatural Agencies, (2) Heredity, (3) Poisons, although it is quite common to find elements of each in the explanation of how any particular leper became infected.

The following are typical explanations of how leprosy came to certain compounds :

(a) "A certain thief was very poor, and had neither food to eat nor clothes to wear. One day he went to his friend's house to beg food, and on his way he met a leopard who asked him where he was going. The thief remained silent, so the leopard cursed him. "As I am now spotted, because of my wickedness in eating whatever I find, so also may you be spotted." The thief went on his way, treating the leopard's curse as a joke, and soon met his friend. Whilst in his friend's house, the thief was studying where his friend stored his goods. When night came he hid himself in a corner, awaiting his opportunity. Eventually the friend, unable to find his guest, went out to look for him. The thief then took what he wanted, and ran away. On his way, he had to pass a certain spotted tree, and when he reached this tree the spots from the tree fell on him. In this way the thief became a leper, as a result of the leopard's curse. Thus, when a native doctor tries to cure leprosy, he must bring the bark of that tree, the hair of a leopard, and these, mixed with sand, must be rubbed over the whole body."

(b) "We believe that the leper got his disease by offending Kamanu Eze Elu, the God of Sea and Sky. Others believe that Obiah, the Creator, punished with leprosy any who fished in a river called Miri Obioh. In my town there was a rocky river-now dried up-in which there lived a man-beast. One day a man shot idly into the river and, to his surprise, found he had killed the monster, the son of Kamanu or Utakpo, the 'Judge of the Dead'. When he reached home mourning, he found himself covered with black and white patches, and this was Utakpo's punishment to men. We believe that a day 
will come when the sun will rise from the West and all our streams come together into a large fountain. Into this the lepers will drop their sacrifices and be healed immediately."

(c) "Two men had a serious quarrel about a piece of land. Neither would give way and the case was taken to the Court. The man who had won suspected that his opponent would try to do something evil to him, and put watch-men about his yard. One night they saw a tall man, entirely naked, stealing into the yard. They watched him patiently until he had hidden the poison into the roof of their master's house, and then sprang upon him and found he was the eldest son of the man who had been to Court with their master. In the morning the captive was compelled to put the poison in a bucket of water and bathe. A few days later leprosy appeared in his body."

The disease may be a punishment for some offence against the gods. It may have been deliberate sacrilege, or neglect to perform some religious rite. Idle thoughts, and words about the local deities, or assisting a leper whose disease is a punishment, are sufficient to bring down the wrath from above. In this type of case the disease passes to the next generation, until all offspring of the offender are wiped out. The disease is latent in the blood of all offshoots of the family, and so, although one man may escape, his son may eventually be attacked.

Contact with a leper is regarded as a secondary cause only; leprosy can only be contracted in this way when there is a history of leprosy in the individual's anticedents. It is thus not sufficient to be sure that a prospective bride is not a leper, but it is advisable to see that none of her forbears has been infected, lest the sons of the brigegroom be attacked. Thus, villages containing a large number of lepers have a greater proportion of unmarried men and women. Heredity and susceptibility are both recognised, but are given an atmosphere of the supernatural. When leprosy breaks out in a man, it may be he himself, or it may be his ancestors that have provoked the gods to vengeance. If there is to be an attempt at cure, the aid of the priest is, therefore, necessary to discover the nature of the offence, and any treatment must be accompanied by sacrifice and penance. Such leprosy is, however, usually incurable-as a saying aptly puts it, "Death cures it."

Many are the afflictions and misfortunes in West Africa that are ascribed to poison, either in the form of noxious substances applied to, or taken into the body; or in the form of magic working at a distance; or through some charm. Mosquitos, lizards, centipedes, millipedes, bugs, cockroaches, have all been blamed for injecting poison through bites, 
whilst spiders' webs and the juices of certain plants are said to have had the same effect merely by contact. It is believed that certain people can manufacture a poison, which, entering into a man can produce all the symptoms of leprosy. Such poisons can be bought-usually with an antidote to protect the buyer. A common method is to put the poison in the roof of the enemy house, when the rain will dissolve and wash the ingredients into the man's drinking pot. Again, it may be smeared on some tree that the intended victim is likely to climb. In such cases the poison works both by physical means and by magic. A frequent custom consists of tying a fine thread around a farm, with one entry known only to the owner. In this way the farm is protected from theft, for anyone entering the farm by any but the proper way will develop leprosy as a result of contact with the thread. Such leprosy may be cured, though it often becomes chronic as a result of the patient's misdeeds.

The methods of treatment are legion, but they resolve themselves into frequent bathing with medicaments prepared by the native doctor, the drinking of potions, and the scarification or cauterisation of the patches. During treatment the patient may have to live under supervision by the doctor and do work for him. The medicines used are prepared from crushed shells, crushed roots, powdered bark, leaves, fruit-juices, parts of animals and fishes, and other ingredients known only to the doctor. The patches are treated with native preparations intended to cause blistering of the skin; or burnt by rubbing with hot ashes; or fire in some other form; or scraped, with or without some form of premedication. When the wounds are healing, pigments or dyes may be rubbed in, to help to restore the normal colour.

In many cases the leper is isolated when recognised, but if his family is powerful the attempt is resisted and money is spent in making the disease non-dangerous to others. When isolation is achieved, a hut is built some distance from the town, and the leper is not allowed to leave it until the morning is well advanced. It is an evil thing if the first person seen in the morning is a leper; it is necessary to undergo some ceremonial cleansing and to sacrifice, lest the sickness result.

As the disease is so much feared, people are ever on the watch. In some towns the elders hold periodical inspections of all the inhabitants. When a man makes his overtures to the parents of his prospective bride, he goes in native dress (loin-cloth only). Until he is married he assists in the farm of his bride's parents, during which time the couple have 
opportunity to assure themselves that they are both quite free from infection. No man will wrestle with a fullyclothed opponent. Anyone who is always fully-clothed is under suspicion, and at village feasts, native costume is the official dress.

The death of a leper is a sordid end to a miserable existence. In many places originally murder was the only effective prophylactic known, and many who were not lepers must have suffered this penalty. The actual customs vary, but generally the leper is not allowed to die in the town, if it can be avoided. Just before the end, men hired for the purpose and fortified with an antidote, escort the sufferer to the "bad bush," and watch that he does not return. In other cases, the grave is prepared just outside his house and the leper pushed inside whilst still alive. Immediately death takes place, the grave is closed, the house broken up, and a fire lit over the grave to destroy the sickness as it leaves the body to enter into someone else. The property of the leper goes to those who conduct the burial, with the exception of money, which alone goes to the next of kin.

It is not to be supposed that the foregoing is a complete list of all the beliefs, ideas, and customs associated with this disease, or that all that is described is common in every village. There are very many variants even within a comparatively small area.

The introduction of education and of the various European contacts has done, and is doing, much to displace long standing practices. This is a good thing, for the aetiological factors of heredity and contagion already recognised by the people need to be shorn of their clothing of magic and native religion. It is an evil thing, however, when western contacts mean that the native doctor can add to his list of medicines, potassium iodide, strong and poisonous disinfectants and liniments, and many other drugs, all of which can be procured from the leading companies, or bought in the open market. I have seen many tragedies due to the indiscriminate and ignorant use of such remedies.

It should not be difficult in a leprosy campaign to find useful material among the peoples' own ideas, on which to build. It is surprising at first perhaps that with such fears, and such methods of isolation as have been practised, leprosy should be so prevalent. It must be realised, however, that restrictions attempted in ignorance of the true dangers are bound to leave many loopholes, and that the greater commingling of the population, together with the less serious regard to the prohibitions of native tribal life, are now helping to make the problem of this disease more urgent. 